\title{
Public Policies Under Tension: Tourism and Environmental Protection - A Case Study in Patagonia
}

\author{
By Liliana Lolich* \\ Tomás Guevara ${ }^{\dagger}$
}

\begin{abstract}
The creation of the Interdisciplinary Centre for Studies in Economics, Territory and Society (CIETES) inside the Andean Seat of National University of Río Negro gave us the opportunity to conduct a research of an urbanized area next to the Nahuel Huapi National Park in Patagonia. It is protected by the local government as a Natural Urban Reserve. The study inquires about the impact on the development, especially in relation with the real estate market. It is based on human statistics, the census, the land uses, the physical area, the tourist and recreational attractions, the environment and the urban legislation for control and conservation. The information was mapped and analyzed with the inhabitants. It concludes with recommendations for a better relation between the environment conservation and the touristic development, strategies to improve town planning and to increase and deepen the studies of the history of our regional architecture.
\end{abstract}

Keywords: Heritage, Patagonia, Sustainable Development, Tourism, Town Planning, Wetlands.

\section{Introduction}

The mythical lure of Patagonia has been constant throughout its history. Since it was discovery, this land has inspired many legends and even today is presented to the world as a land of fantasy and mystery. The place name derives from "Patagones", the word used by the Portuguese sailor Ferdinand Magellan to identify the natives he found when he reached the shores of the area in 1520, for the first time. He used a term drawn from the novels of chivalry.

The construction of this imagery is reinforced by its territorial vastness, which is about one million $\mathrm{km}^{2}$, and is equivalent to the territorial space of several European countries. Even today, to make a tour along this land, people must endure exposure to loneliness and climate rigor, because of its inhospitable geography which is crossed by strong winds. One of the fantastic legends of Patagonia is associated with the City of the Caesars that is

\footnotetext{
${ }^{*}$ Research Scientist, Consejo Nacional de Investigaciones Científicas y Técnicas (CONICET) \& Universidad Nacional de Río Negro (UNRN), Argentina.

${ }^{\dagger}$ Research Scientist, Consejo Nacional de Investigaciones Científicas y Técnicas (CONICET) \& Universidad Nacional de Río Negro (UNRN), Argentina.
} 
considered to have had enormous wealth and large gold deposits, but was never located.

Patagonia is a large wedge between the Atlantic and Pacific oceans and its southern apex is the worlds' closest body of land to the South Pole. The population is sparse, less than $2.5 \mathrm{Mhab}$, it is estimated to have 2.2inhabitants $/ \mathrm{km}^{2}$ scattered and concentrated in a few urban centers centres. Neuquen, Comodoro Rivadavia and Bariloche in Argentina, and Punta Arenas in Chile, are among the most populous cities, with more than one hundred thousand inhabitants. Chile has modified its northern boundary of Patagonia acquiring latitude similar to Argentina.

With the exception of the Andes Mountains, Patagonia is a large plain that occupies the entire central area, broken into large blocks where there are plateaus that rise from east to west to the foot of the mountains, with altitudes of around 1,000 m, depressions with temporary lagoons and steppe vegetation. The Patagonian rivers have the peculiarity of being the only Argentinian rivers that originate in the mountains and flow into the ocean. Their presence was crucial to the location of the cities.

The Andes split the territory longitudinally, with heights reaching up to around 3,300 $\mathrm{m}$. Transversal valleys are carved from glaciers of low height that facilitated, since ancient times, the communication on both sides of the mountain range. In contrast to the plain, the Andes have fertile lands and are suitable for human settlement. Because of their lush forests and blue lakes, they are considered protected areas. Among them is the Nahuel Huapi National Park with which our case study focuses on.

This study corresponds to an interdisciplinary research linked to the socioenvironmental problems. It includes knowledge of urban planning, sociology, architecture, economy and tourism. Comprising the diagnostic study on the Nature Urban Reserve (NUR) called "Lago Morenito-Laguna Ezquerra" in adjacencies of the Nahuel Huapi National Park in Bariloche ${ }^{1,}$ Patagonia Argentina, in the southern part of the Americas ${ }^{2}$.

The working method focuses on office activities and field campaigning where regular meetings of the local authorities and specialists from the Universidad Nacional del Comahue, who were in charge of the study of the natural environment, are held. We worked with graphic and photographic documentation, both historically according to our own records, along with statistical information. Plus, the analysis and interpretation of secondary sources was also carried out. We used the Geographic Information System (GIS) for recording the survey for both physical and socio-economic observation. They were interviews and workshops with the inhabitants and representatives of the Neighborhood Council. This Council is part of the local governance.

\footnotetext{
${ }^{1}$ Bariloche is in the province of Río Negro, at the foot of the Andes, the Chilean frontier. Georeferenced location: $41^{\circ} 09^{\prime} \mathrm{S} ; 71^{\circ} 18^{\prime} \mathrm{O}$. The Park covers 750,000 ha. The watershed of Lake Nahuel Huapi comprises 600,000 ha.

${ }^{2}$ Part of this research is registered in the document: Oglietti, G. et al. 2014. Financed by the Municipalidad de San Carlos de Bariloche (Res. 2857-I-2013).
} 
The full report consists of seven sections that include the description and characterization of the area; record of stakeholders, agencies, interest groups and institutions, interfering with the NUR; historical information related to the process of occupation and settlement of the Lake Nahuel Huapi; analysis of urban and environmental policy; survey and mapping infrastructure, equipment and urban public services; surveying and mapping of land use; surveying and mapping work built; analysis of space and landscape survey and its mapping; socio-demographic characteristics and dynamics; and a report of recreation, leisure and tourism activities. The inform ends with a proactive body.

The NUR is a form of protection that seeks to conserve vulnerable habitats through the wise use of wetlands, biodiversity and, because of that, the longterm human well-being. It includes a Joint Commission for the development and implementation of a management plan. The Commission is integrated from government representatives and inhabitants, who can exercise control and continuous monitoring.

\section{Environmental Policy: Its Origins and Process}

Globally, the institutionalization of environmental protection began in the United States after the establishment of the Yellowstone National Park in 1872. Since then, theories have evolved from strict conservation and sustainable use of biodiversity. This is linked to the category of "protected areas". Today a natural environment without cultural components is inconceivable since even "intangible" areas require human intervention for their care and protection.

In 1934 the government of Argentina created the Nahuel Huapi National Park, which is the first and oldest national park of the current thirty three existing parks. It was administrated by the Dirección de Parques Nacionales chaired by Dr. Exequiel Bustillo (Figure 1). Before, in 1922, the Parque Nacional del Sur had been created which, however, failed to reach a politicalinstitutional figure (Núñez 2011). 
Figure 1. The Nahuel Huapi National Park, Argentina

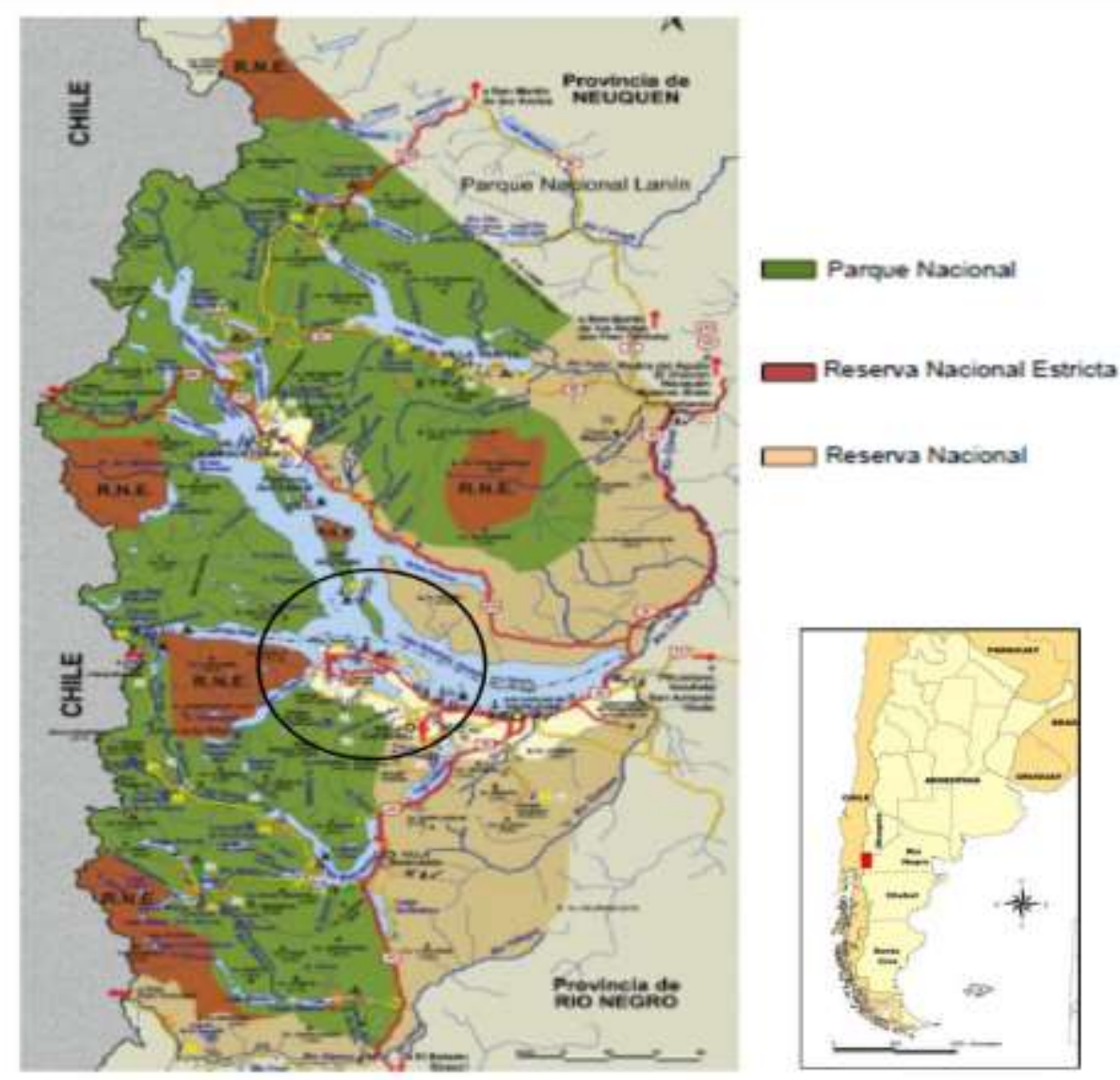

Note: The circle's centre shows the area of study.

Source: By authors, based on Plan de Ordenamiento Territorial (Municipality of San Carlos de Bariloche 2010).

Francisco P. Moreno (1852-1919) was a scientist who worked as an expert and explored the area. His studies allowed determining the frontier that Chile and Argentina agreed in 1902. In return, the Argentinian state granted him a share of the land. He donated part of it for the creation of a state park, which is now part of the current Nahuel Huapi National Park. This was an area with settlements of scattered pioneers whose economic livelihood was mainly cattle breeding. The town of Bariloche, inhabited since 1895, along with another suburban and rural settlements, were included inside the Park.

Thus, since the creation of the National Park, the conservation of nature coexisted with previous settlements which were increased by the creation of new tourist villas. This made it very difficult for the city administration, to overlap governmental jurisdictions. In the case of Bariloche it was resolved in 1958 with the so-called "Luelmo Law" that defined the local ejido, which separates it from the park (Vallmitjana 1989). 
Why a NUR?

One of the distinctive characteristics of the protected areas in Latin America, unlike the northern hemisphere, is that they contain human settlements. As we saw, Argentina is no exception. Hence the need for publicprivate strategies, the government shared governance with indigenous peoples and local communities.

The NUR were created in 2007 for the Municipal Charter as a figure to manage urbanized nature areas. The neighbours may ask a declaration of a protected area or an urban nature reserve through the participatory mechanisms provided (Art. 188). This is a participatory management tool that requires initiative and voluntary participation of the locals. It recognizes, as antecedent, a set of previous NUR that includes The Clover Lagoon (Laguna El Trébol), High Botanical Garden (Alto Jardín Botánico), The Forest Hermitage (Bosque La Hermita) and The Cards (Las Cartas).

It is a tool that seeks to empower the settler, increasing its capacity controller. The character of NUR is part of the current strategies that seek to enhance local governance and to acquire more efficient and sustainable environmental protection. It corresponds to the category V: Protected Landscape, provided in the Provincial Law No 2669and is a Natural Protected Area, which despite urbanization, has ecosystems that are in good condition.

As defined by the International Union for Conservation of Nature and Natural Resources (IUCN), a protected area is "a clearly defined geographical space recognized, dedicated and managed through legal or other effective means to achieve long conservation term nature and its associated ecosystem services and cultural values" (Dudley 2008).

One of the highlights of the ordinance 2030-CM-10 that creates the NUR "Morenito-Ezquerra Lake" is the suspension of new divisions and subdivisions of lots and the construction sites, with the exception of those for individual permanent housing, until the Environmental Management Plan for the area is approved.

\section{Study Area: Characterization and Peopling}

This area is located northwest of the Argentinian Patagonia, at the foot of The Andes Mountains. It is comprised within the municipal ejido in the interface area with the Nahuel Huapi National Park. The Morenito Lake and the Ezquerra Lagoon are part of the watershed of Lake Nahuel Huapi, across the Moreno Lake.

The Nature Urban Reserve (NUR) "Lago Morenito y laguna Ezquerra" located west of the urban area, covers 265 ha of surface and is divided into 30 blocks with a total of 253 plots. The Morenito Lake and its tributary, the Ezquerra lagoon, provide water to the Lake Nahuel Huapi, one of the most important lakes in Patagonia. Originally, they were a part of the lake Moreno until the 1960s when an embankment was built to provide vehicular access to 
the island of the Bariloche Musical Camping from villa Llao Llao. This limited the connection between the two bodies of water to a small canal (Figure 2).

Figure 2. Location of the NUR in the Ejido of San Carlos de Bariloche

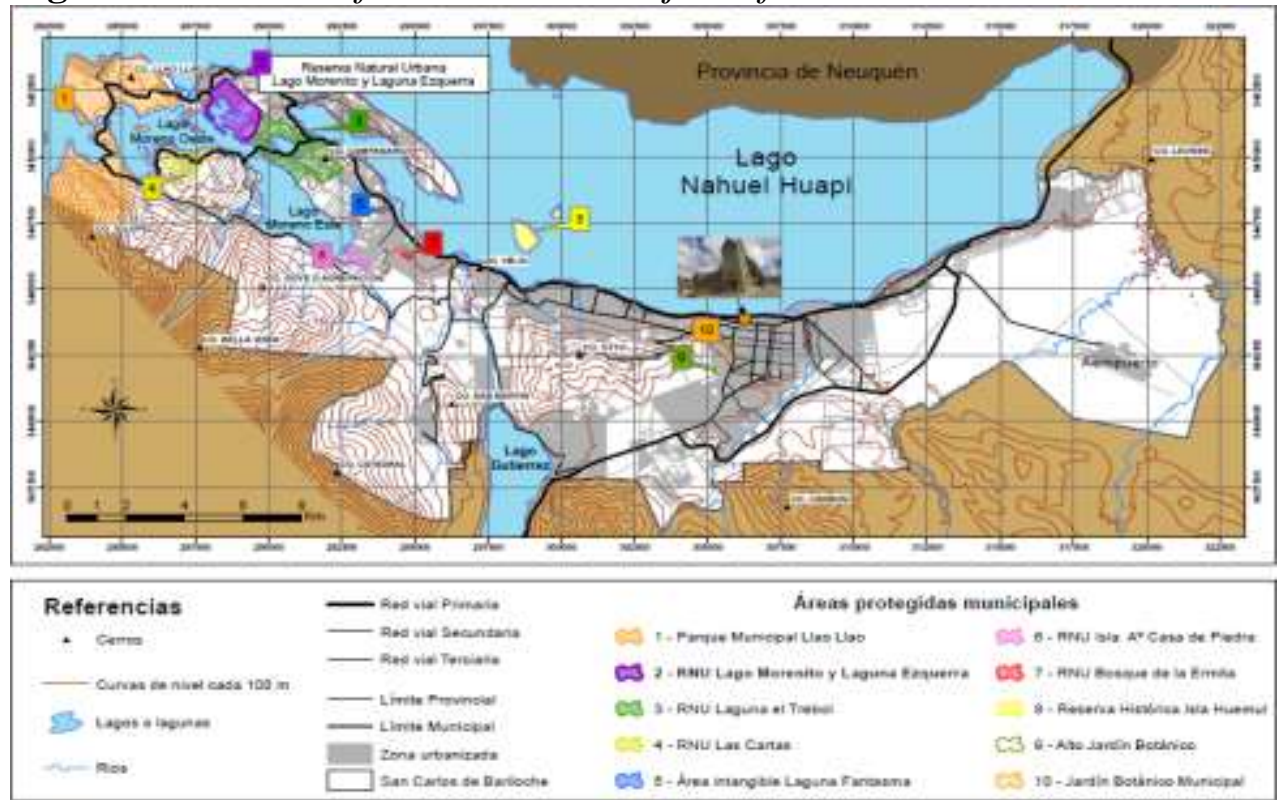

Source: By authors.

The Morenito Lake covers an area of about 80 ha and is mostly surrounded by residential neighbourhoods (Figure 3). By anthropization the waters of the lakes in the region have lost their characteristic transparency, and have adopted an amber color that demonstrates the presence of organic substances that are threating the environmental balance.

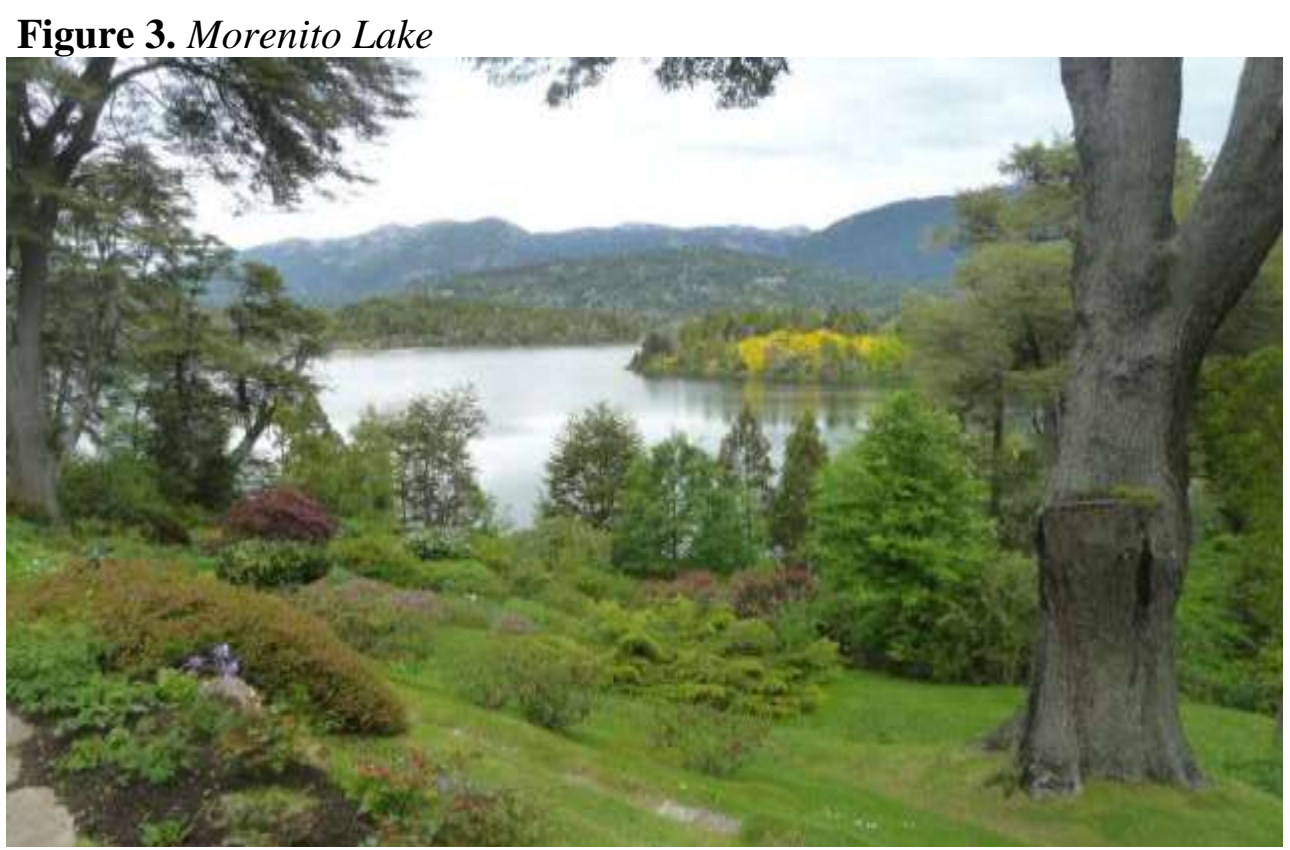

Source: By authors. 
The Bustillo Avenue that borders the Nahuel Huapi Lake connects with the city of Bariloche, located $25 \mathrm{~km}$ towards the east. This large lake, extending from west to east registers a sharp contrast in the rainfall that exceeds $2,000 \mathrm{~mm}$ annually at its western end, with the predominance of rainforest, to less than $400 \mathrm{~mm}$ annually in the east. The greater altitude over the sea determines a greater frequency of precipitation at the west, near the mountains.

\section{Occupation and Settlement Process}

The records of human activity in the area consign a higher age to 10,000 years. Among the indigenous groups of the area, previous to the conquest of territory by part of the Argentine government, are highlighted as the Puelches, a Mapuche ${ }^{1}$ designation translatable as "people of the East". One of its most prominent features was their ability to scroll with canoes, which allowed them to live on the islands and shores of the lake, especially on the north.

The independence of Spain led to the emergence of the Republic of Argentina which had an economy based mainly on farming. This type of economy required the incorporation of new lands to the south: the indigenous territory of Patagonia. The policy resulted in the military campaign led by General Roca (1875-1889), his indigenous genocide and to the incorporation of the country into world capitalism as a producer of raw materials and food for the foreign industries (Navarro Floria 1999).

After that, the early pioneers in Bariloche and their zone of influence began to settle. Among them, the presence of Chilean immigrants was important, along with creole and European centre immigrants (Matossian 2013). The formation of the National Territories in these new lands (Law 1532/1884) in 1902 led to the foundation of the Nahuel Huapi Colony and the consequent granting of the land around the lake, promoting the establishment of settlers in plots of 625 ha.

The economy was based on cattle breeding, grain cultivation and forestry. The isolation with the rest of the country and the lack of border controls favoured the development of an important cultural and commercial exchange with Chile thanks to the low height of the mountain passes and the navigability of the lakes. The studies in the region of Araucanía (Chile) - Norpatagonia (Argentina) show a high degree of social and economic integration until the 1920s. The whole area was involved with the movement and marketing of cattle and timber since the installation in 1895 of the Chilean Carlos Wiederhold, recognized as the first settler of the Bariloche area. His presence led to the establishment of a subsidiary of a German company called "Commercial Company and Livestock Chile Argentina" and was headquartered in the Montt Port with a direct connection with Hamburg. After the Second War, the firm was sold to Primo Capraro, an Italian immigrant who was noted for his entrepreneurship, until his death in 1932. He was the owner of a hotel in Bahia Lopez from where many goods were embarked to Chile.

\footnotetext{
${ }^{1}$ The Mapuche were natives of the western slope of The Andes Mountains.
} 
The area of the Morenito-Ezquerra Lake was part of the route of waggons which went to and from Bariloche. This route joined the ports that Capraro administered at both ends of the Nahuel Huapi Lake, before continuing their trip to Chile by Blest.

When customs controls began, the regional economy was dismantled and a new stage began. It was characterized by the crisis of agricultural practices and sovereignty policy by increasing internal migration. The hypothesis of conflict with Chile was imposed, together with xenophobic policies.

A new territory began in 1934 with the arrival of the railroad, the creation of the Dirección de Parques Nacionales and the appointment of Dr. Exequiel Bustillo as the director led to a significant geopolitical change (Bustillo 1999). Those interconnections to Chile were cancelled and replaced by a vertical connection along the foothills of the Argentinian Andes. The economic model of development was based on tourism, in particular tourism of elite demand. Hotel capacity increased from 330 hotel-beds in 1930 to 1,500 in 1934 (Vallmitjana 1993, Vejsbjerg et al. 2014). As a direct consequence, the real estate business prospered quickly. In less than a decade, tourist arrivals increased from 600 to 4000 .

Among the numerous public works materialized during the "decade Bustillo" (1934-1944) to provide adequate tourist facilities, we highlight the creation of a system of tourist villages with which it was financed. The most significant urban projects were made by the architect-planner Ernesto Estrada. They were destined to create plots for private buyers: tourists who built their summer homes in the villas, between them, the Villa Llao Llao which currently has a sector integrated into the NUR.

When the Bustillo's decade culminated, the improvement of the situation of the working class introduced by the Perón's government, social tourism and mass tourism began. In the early 1950's, 55.000 annual arrivals in the city were recorded, while the city's population was only about 7,000 inhabitants. Social tourism was aimed at giving greater impetus to camping and labour unions. Several hotels were converted in that sense, for students, retirees and employees. In 1958 the Law 14,487, known as the "Luelmo law", allowed to the Bariloche's ejido to incorporate the land formerly owned by the National Government agencies, including the urbanized part of the Parks. Subdivisions approved before 1960 invaded the forested areas.

\section{Tourism in the Regional Economy}

The high scenic attractiveness of the area was understood to boost tourism development. The Chile-Argentine Company, other than their six major cattle ranches of the Argentinian Patagonia (420,000 ha) north, built hotels, roads, ports and, also, they installed boats to travel between the Montt Port and Bariloche. This prompted the first tourist experiences into the area, in a system that integrated hotels, land and lacustrine transportation. As Hiernaux (2006) notes, a part of the social and territorial process of touristification to give answers to the new demands for tourism and recreation is the introduction of 
changes in the territory by building new infrastructures and equipment. Thus there are new images and new actors. All space is modified by the introduction of a new function.

Along with the increased amenity migration and its economic, social and territorial consequences, the demand for housing as a "second home", "summer home" or "winter home" for skiing and other mountain sports, increased. As in other mountain tourist destinations, the effects are multiplied by the excessive empowerment of the corporations related to real estate and rigged by tourism.

In this way, the real power dominates the power formally constituted, in our case, the governance of the local municipality. The creation of the legal figure formed by the NUR emerged as a strategy to counteract negative impacts on the environment, both cultural and natural.

\section{Problems for Environmental Risks}

One of the most important natural risks is given by the proximity of the volcanoes with their associated seismicity. Among the erosive factors are the almost permanent presence of strong winds and rainfall intensity. Besides, human activity causes flooding and landslides, avalanches, debris flows and rock-fall other mixed effects (naturalanthropogenic) that should be taken into account are water pollution and soil and forest fires.

\section{Cultural Environment}

Until the 1920s, communication was more fluid with Chile through the lake than with the rest of Argentina, determining a high degree of bi-national integration. This determined a great isolation from the rest of the country. It is therefore no coincidence that the constructions carried by the first settlers turned out to be similar to the traditional architecture of southern Chile, after German immigration arrived at the country since 1850 . To reach Valdivia from Bariloche only three days were required. There joinery, furniture and building materials could be bought. On the other hand the journey to the port of San Antonio Oeste, on the Atlantic coast, took more than a month. This allowed the development of proto-industrial architecture, made of wood, fabric and a rationalized system.

Both the political and administrative organization in national territories such as the National Park itself, until the mid-twentieth century, had a significant dependence of the national government, with little and sometimes no possibility of local governance. The influx of this dependency continues, dominating and weakening local governance. Among the practices that were held in this time was the concentration of land, in many cases, on a discretionary basis. Far from the exploit of its comparative advantages for investment, they promoted and promote speculative and rent-seeking practices at the expense of other people and the implementation of effective environmental protection. 
The process of land development was increased in 1940 and 1970 on the basis of the subdivision of the first land plots previously destined to rural activities. The first subdivision was made by the real estate entrepreneur Vinelli, with the experience of wide action across the country. The process involved the purchase of large agricultural plots or farms that were divided into urban lots, without any fiscal reserves or parks, no urban planning or hierarchies and even without opening streets. These works were subject to further state action. Thus, the alleged "developer" transferred to the society the most significant investment. The lots intended for tourists were sold in Buenos Aires and other important urban centres.

In our study area, this phenomenon is evident in the process of appropriation of land where the national state built the Lake Moreno hotel and then granted it in concession to the Teachers' Union. Through obscure manoeuvres, the property was privatized without the local government and justice dared to intervene (add journalistic reports). The surface represents 18 $\%$ of the study area and is the only one that could not be surveyed due to the refusal of the owners to facilitate access and the obstacles presented by the same municipal body, to see documentation.

\section{Special Features of the NUR}

As part of its biodiversity, we highlight the presence of an important species. In addition to the predominant native, flora provides Schinus patagonicus, Maitenus boaria and Luma apiculata; also Barberis buxifolia, Barberis darwinii, Aristotelia chilensis, Buddleja globosa, Tristerix corymbosus, among others. Inter alia, the wildlife has endangered species like Lontra provocax and Dromiciops gliroides, along with the Patagonian bird carpenter (Campephilus magellanicus), Cleophaga picta and C. polyocephala, Theristicus melanopis and waterfowl nesting in the reeds surrounding the lake, such as Podiceps major and a variety of ducks; while among the fish stand the Patagonian silverside (Odontesthes micolepidotus) and smallmouth perch or Creole trout (Percichthys trucha). It integrates a natural corridor that extends to the neighboring Clover Lagoon NUR and the Municipal Llao Llao Forest and the Nahuel Huapi National Park. The NUR condition helps prevent landscape fragmentation, preserving its integrity.

One of the most significant natural values -at a time when the availability of fresh water is becoming of increasingly global importance- are the wetlands contained within the area ${ }^{1}$. Beyond the importance of the lake itself, wetlands guarantee the balance of the entire system. In this regard, the Convention on Wetlands (Ramsar Convention) provides the framework for action for conservation and wise use.

The Bariloche's Urban Code gives, as local development for this sector of the ejido, the status of the residential area with complement able sustainable

\footnotetext{
${ }^{1}$ Wetlands are formed in places where the water table coincides with the ground surface or close to it or where the land is moistened by the presence of shallow waters such as marshes, swamps or bogs, temporary or permanent, freshwater, brackish or salt.
} 
tourism. It is a place whose quality of landscape needs a proper management in order to integrate a rapidly expanding urban matrix and for it to be accessible to public use. However, the whole area has been starring an increase in building and an intensity of land use, which makes it a highly vulnerable environment. For years a strong oversight of the activities carried out by professionals and technicians has been recommended by many.

\section{Social Features}

The population density is low and the presence of numerous vacant or derelict lands is evident. To this sums up to $43 \%$ of uninhabited houses, a total of 140, which are part of the group of houses of temporary use and are uninhabited most of the year. Since the census radios do not match the boundaries of the NUR we could only work with estimated figures that show a population of around 280 inhabitants, with a density of 1.41 inhabitants/ha 1 .

From investigating what happens in other countries regarding this issue, we find that one of the characteristics of the 1990s in Canada, as in Latin America, was the deactivation of social policy and the halting construction of social housing (Stefanick and González 2012: 1122). Both there and in the United States, amenity migration is associated with the Baby Boomer phenomenon which is associated with the consequences of the Second World War with an increase of births in the context of an economic bonanza. Currently Baby Boomers are about seventy years old, have received inheritances from their parents and because of this many have invested in a second home. While we did not venture to make a direct correlation, surprising coincidences and repetitions in relation to social policies and investment in public works, by the State, and the characteristics of a generation with a strong presence in the sectors of our middle class, are observed.

The amenity migration in the context of increasing mobility of people and populations is understood as part of the consequences of the capitalist and neoliberal globalization. These population displacements are caused in the search for better quality of life, also called style-life migration. They are, in general, people who visited the area as tourists and, afterwards, decide to move there, in a utopian quest of the "lost paradise". Its direct consequence is an increased demand for environmental amenities, both cultural and natural. There is a preference to mountain or sea destinations because they are perceived as places that have not undergone major changes and that will offer a quieter life and a better relationship with nature.

In the recent years this process has been enhanced by the facilities offered by new technologies and telework. One indicator of this is the explosive increase in the construction of country clubs in both large cities and tourist centres on the scale of Bariloche neighbourhoods.

This causes a significant increase in the housing demand which results in an increase in construction but also in runaway inflation in property prices.

\footnotetext{
${ }^{1}$ The gross density for the entire ejido is 3.4 inhabitants/ha.
} 
Along with them, land scarcity, changes in land use and pressure on protected natural areas are evident. According to Stefanick and González (2012), among the characteristics that identify these migrants is the fact that they quickly come into conflict with the native population. Although they often have environmental awareness, most of the migrants are not inclined to engage in community and solidarity actions. They soon miss cities amenities to which they were accustomed to and "may have a limited degree of involvement and local commitment" (Stefanick and González 2012: 1120).

While this has been taking place in our area since 1940, by the international tourist visibility that Bariloche reached, in recent years this process has been enhanced by the facilities offered by new technologies and telework. One indicator of this is the explosive increase in the construction of country clubs or closed neighbourhoods in both, large cities and tourist centres on the scale of Bariloche ${ }^{1}$. The survey that consisted of 253 plots showed that 134 lots $(54.5 \%)$ were in a state of neglect $(28.5 \%)$ or waste $(24.5 \%)$. Figure 4 shows the level of underutilisation of existing parcels as a result of real estate that exploded the tourist attractiveness of the area.

Figure 4. Map Identifying the Different Neighborhoods

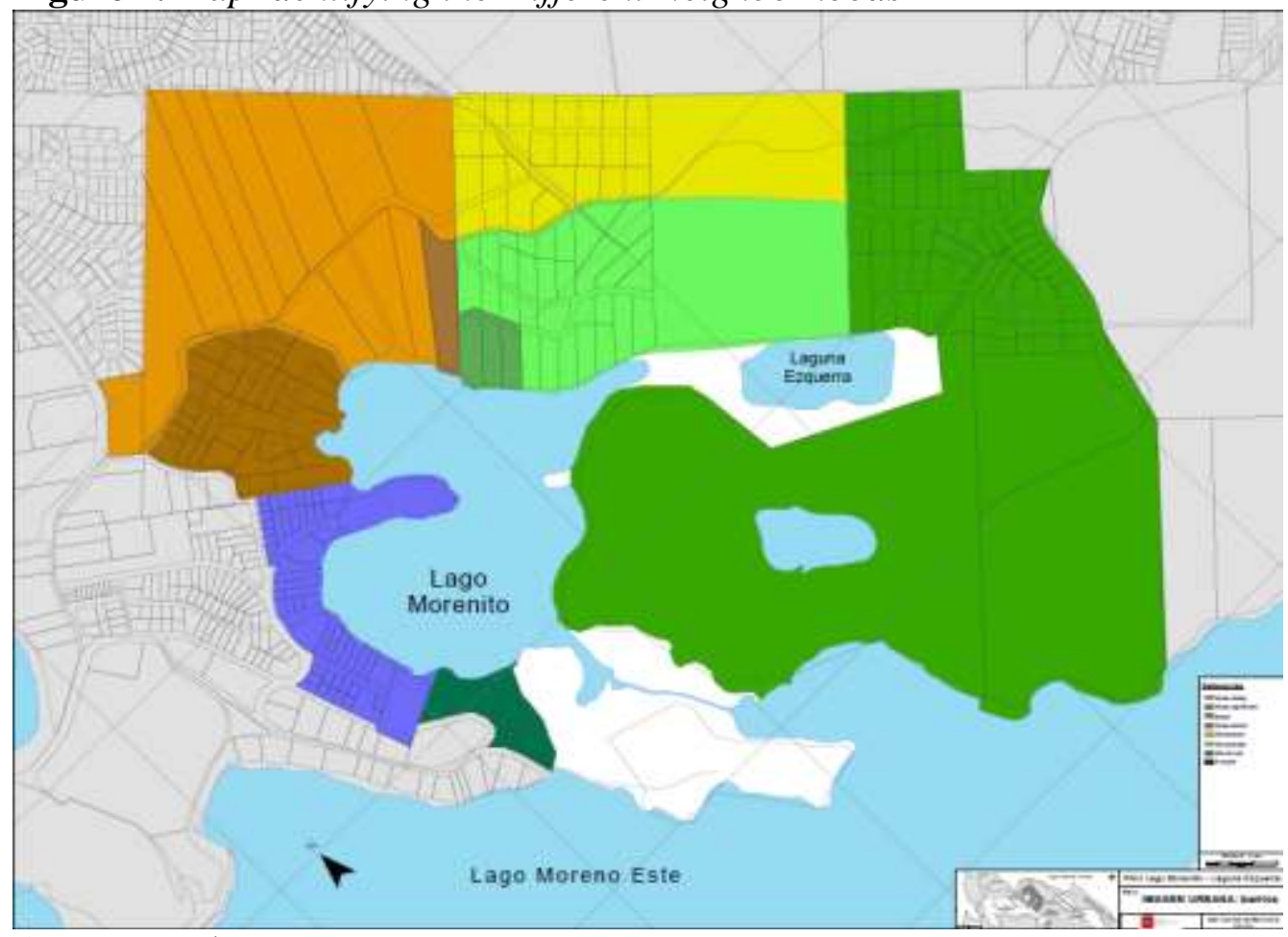

Source: By authors.

In our study, although the declaration of NUR was an initiative of the neighbours who value the natural and cultural attributes and show engagement to their care and preservation, there are conflicting interests that divide them as

\footnotetext{
${ }^{1}$ The Bariloche's ejido has 112,887 inhabitants (Census 2010) and it is estimated that in the year of the census arrived 680,000 tourists.
} 
a group. This seems to also correspond with the existence of a large private plot of NUR separating it into two parts: the northern sector (The Llao Llao Village, Musical, Quintral, Casteigh and Suyai neighborhoods) and the southern sector, adjacent to the Ezquerra Lagoon and The Park Moreno Lake neighbourhood. While the first sector is dominated by second homes of owners who live mostly in Buenos Aires; in the second sector permanent residents predominate. The first sector is also dominated by the housing type villa that is surrounded by gardens and is scenically resolved with an aesthetic vision that devastated the native flora.

In both sectors there are people concerned about environmental conservation and who push for the declaration of the NUR. But they coexist with entrepreneurs interested in the tourist exploitation and that are critical for the municipal regulations.

This allows us to state that this is a heterogeneous area in terms of social, economic and cultural world views and overlapping interests that are often contradictory. In accordance with the aforementioned characteristics, as identificatory of amenity migrants, there are those who favor the real estate development through capitalism associated with increased tourist supply ${ }^{1}$.

\section{Tourist Attraction and Physical Survey of the Built Heritage}

In addition to the landscape qualities given by the presence of the lake, vegetation, topography and the panoramic Andes views, the place is of interest to tourism, leisure and recreation. Among them, the most important are possibly linked to sports practices, boating, fishing, swimming, climbing, hiking and enjoying the sunshine (Figure 5).

Regarding cultural attractions a pending issue is the limited recognition of its heritage, except for the Moreno Lake Hotel (now at risk) and the Musical Camping (Figure 6). Therefore, in our study, we included a mapping of the built heritage which includes data and descriptions, as a base document for future systematic recording inventories.

The historical, cultural and architectural heritage is not recognized and valued, despite its undeniable tourist attractiveness. A clear policy of comanagement with the neighbors and their representative organizations, aimed at preserving the still existing testimonies, is required for this. Especially valuable are the historical records of the wagon road to Llao Llao, and the López Bay along with the buildings and urban equipment elements of the oldest inhabitants. This topic deserves a specific research project, the registration and inventory of both material and immaterial goods (Figures 7, 8 \& 9).

\footnotetext{
${ }^{1}$ The NUR Ordinance was observed by some councilors who questioned the suspension of works established in the regulations, until the Management Plan was made. Such capacity affected interests of Faena Group who presented the project for the construction of a mega resort in lands of the former Moreno Lake Hotel, an important local heritage. Another business group composed of residents of the town Llao Llao had also taken steps for the approval of another building complex in one of the peninsulas.
} 
Figure 5. Urban Image Plane of Nodes and Urban Heritage

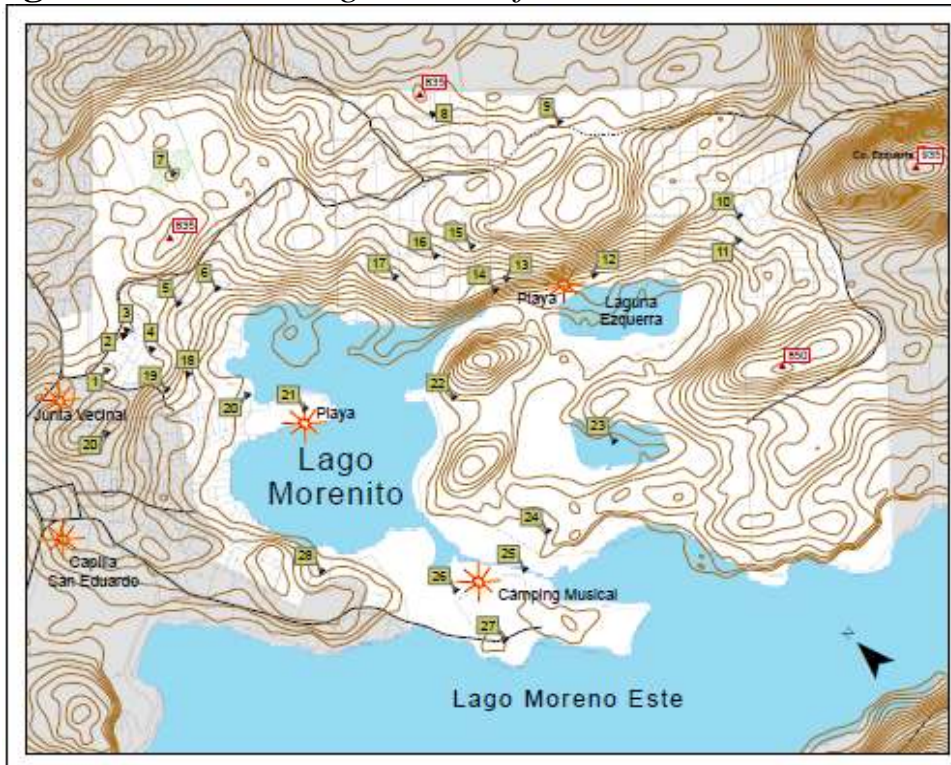

Referencias

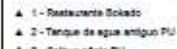

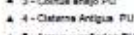

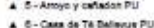

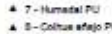

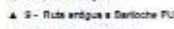

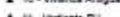

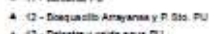

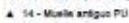

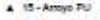

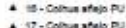

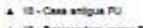

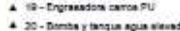

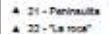

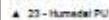

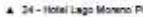

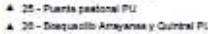

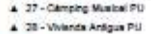

*

Tosment

-omenomesoss
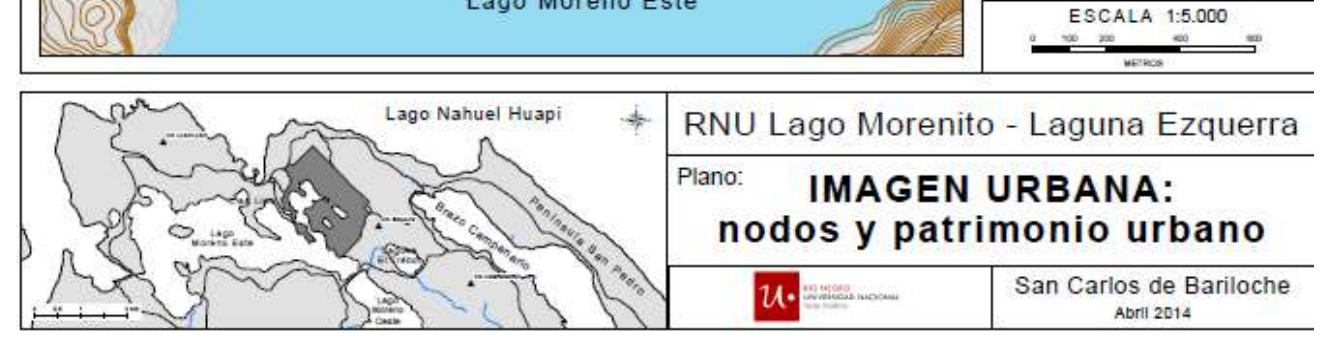

Source: By authors.

Figure 6. Rautenstrauch Hall (built in 1988), Bariloche Musical Camping

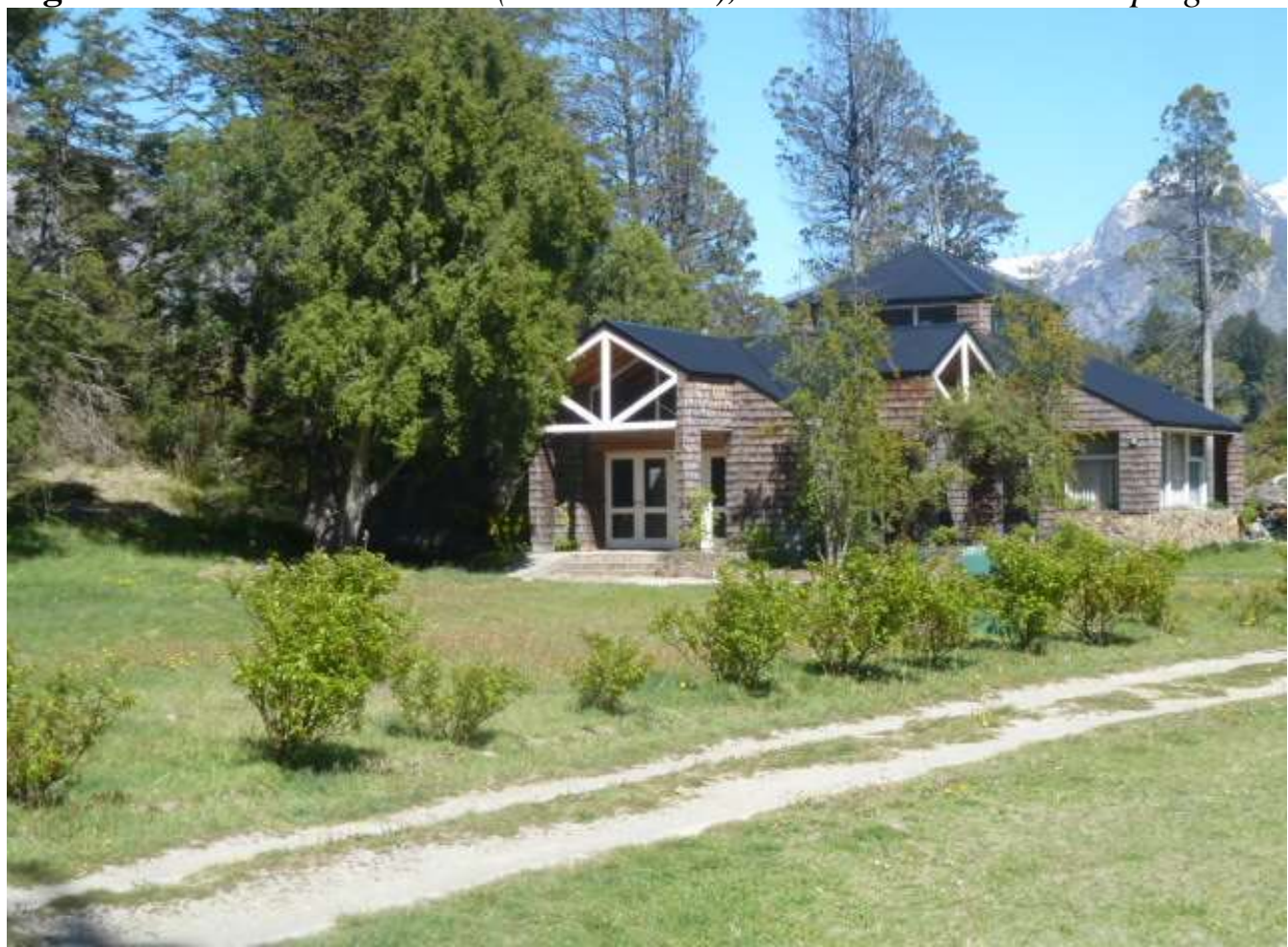

Source: By authors. 
Figure 7. Old Smithy and a Stretch of the Wagons Road

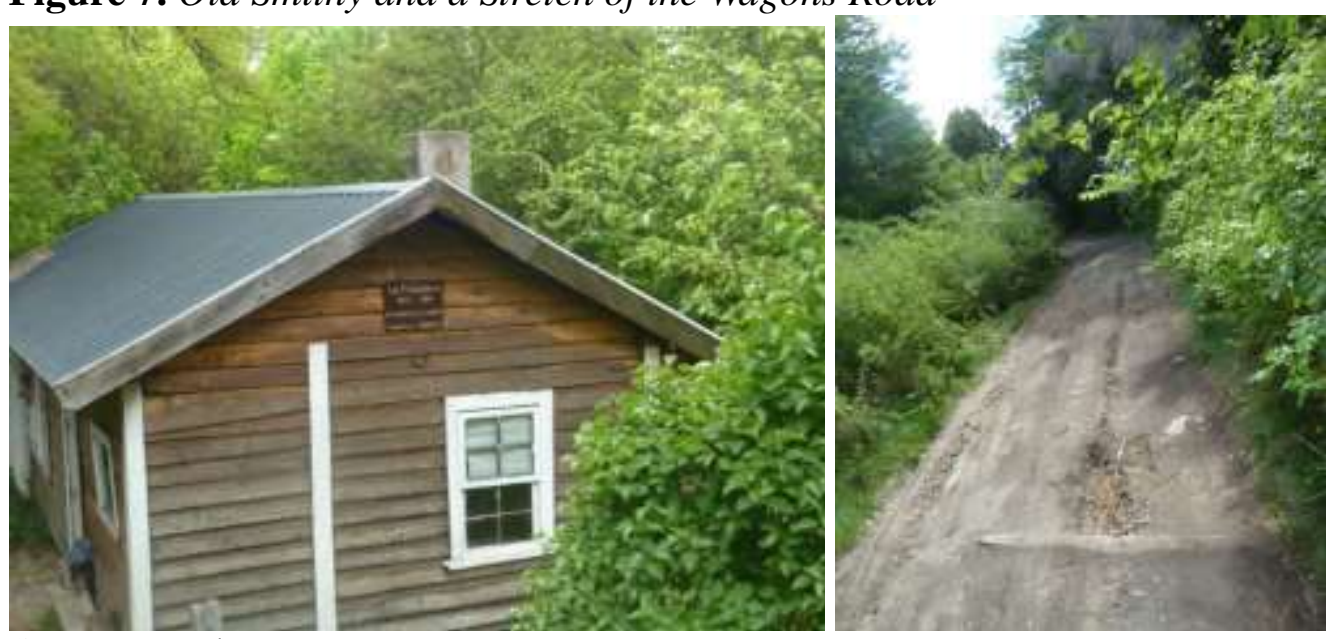

Source: By authors.

Figure 8. An Old Pier

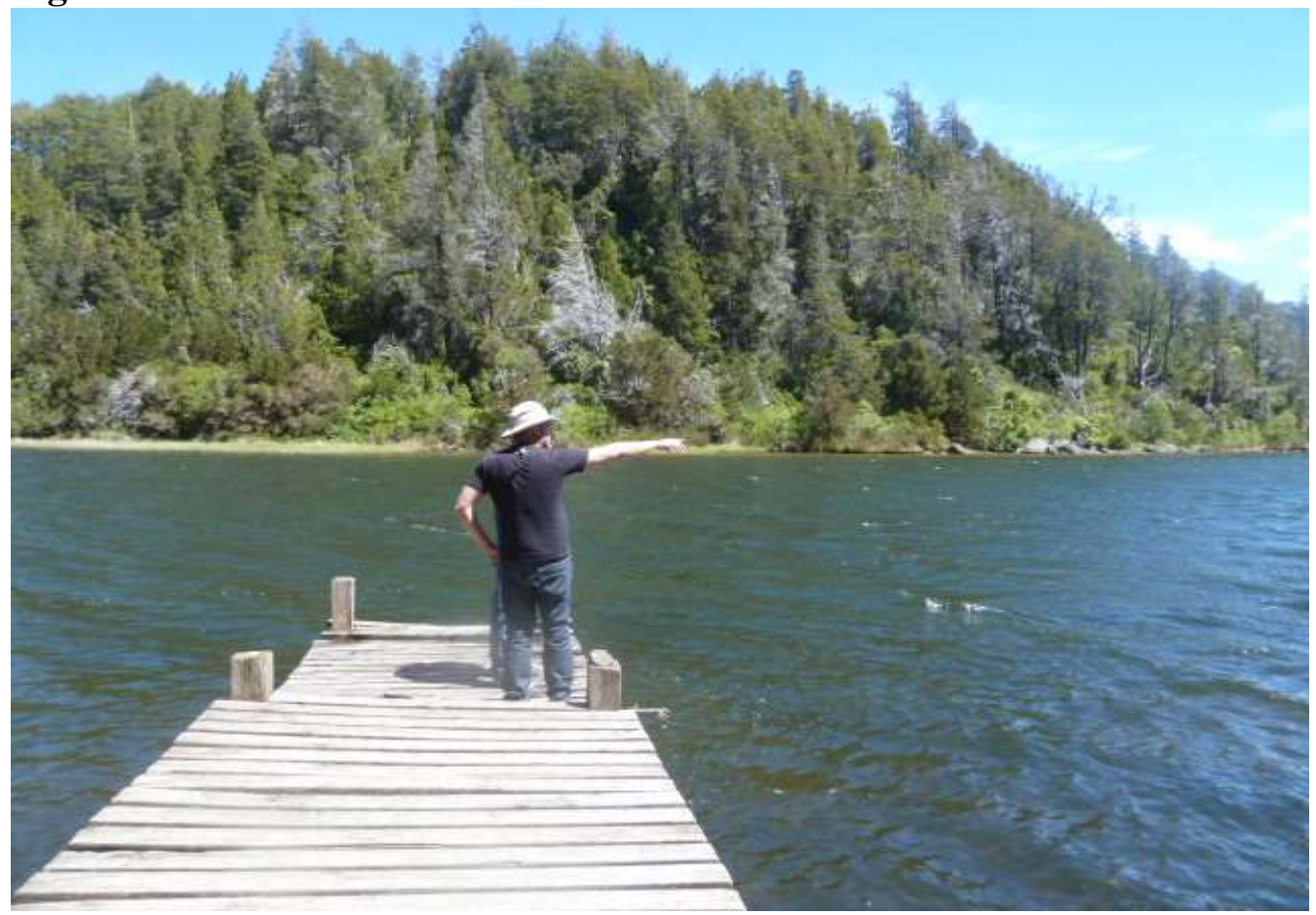

Source: By authors. 
Figure 9. The Moreno Lake Hotel

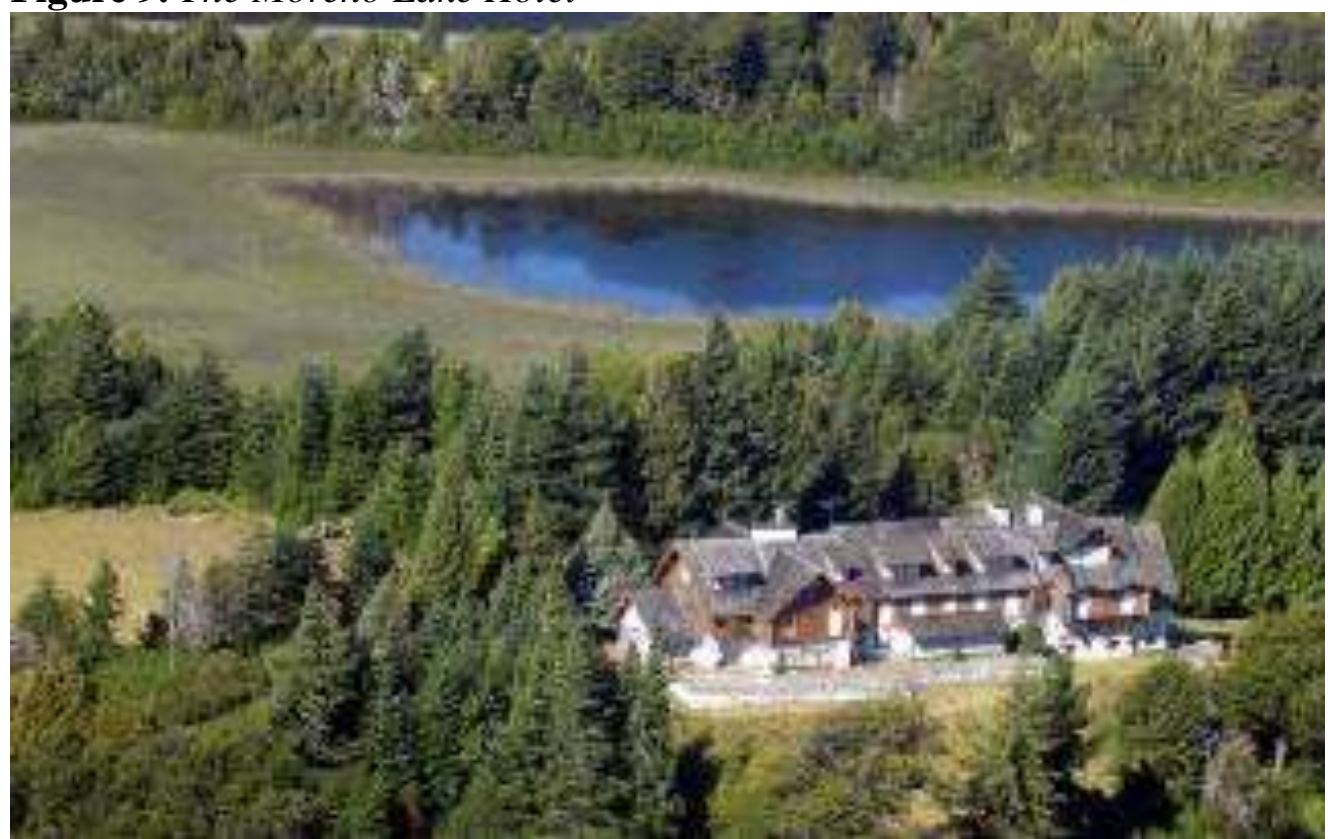

Source: By authors.

\section{Conclusions}

This study was an opportunity to explore and reflect on some aspects that limit the regional economic development. Most of them have to do with the negative effects of tourism and the increased real estate speculation. We delve into how powers that determine urban policies of implicit and invisible modes in a destination that has not been planned. Indeed, Bariloche has had many urban plans that multiplied and overlapped criteria, creating confusing and complex interpretations. This anomalous situation is not innocent. It is part of the interests that are related to the local real estate sector.

International agreements on sustainable development with social inclusion fail to contain, in many cases, the abuse of market related interests, which privilege their interests over the rights and welfare of the majority. In other researches, we have studied the progressive destruction of the heritage caused by the real estate speculation in alliance with the tourism interests (Lolich 2010). Also, other studies account for the damage to the natural heritage. All of them are irreparable.

Tourism is recognized as the most important economic activity of the area. Some authors use the phrase "the tourism's shadow" to refer to the effects of real estate speculation over the urban space (Otero and González 2012). The expression implies an innocence that is not real because tourism has its own ethic rules that are not applied here.

As we have seen, the demand for attractive environmental resources is increasing. Their claimants are tourists who become people with little social commitment. The search for the "lost paradise" is oriented to personal 
satisfaction as a priority without interest in involvement in the defence and protection of the environment they enjoy. In this sense, historical heritage tends to act as a forum for social cohesion for its ability to build cultural identity and a sense of belonging.

The commitment of tourism to poverty must be viewed through the compensation for plus valia (Guevara 2015). It is an activity that ignores the situation of its employees. They have a lot of problems related with the high costs for rent or for purchasing a house to live. Instead of transferring the problem to the public sector, the tourism operators should resolve the situation as well as the secondary sector of the economy make. They should also make significant investments in the workers' housing in order to avoid the proliferation of slums.

We believe that the figure of the NUR is a valuable alternative that, if properly used, can contribute to local empowerment, the creation of partnerships and collective consciousness. To reach a sustainable development, the inhabitants must be committed to participation in governance. In this case the key is the organization of the neighbourhood councils as representative bodies so they can exercise the control and monitoring. By this way they can claim for their rights and ensure that the good intentions in their political speeches declaimed, come true.

In more specific terms, a comprehensive protection of the watershed study area requires expanding the boundaries of the NUR to ensure the continuity of the environmental corridor and to avoid both cultural and natural fragmentation. This would involve assessing the creation of a new larger NUR, including the NUR El Trébol and the Parque Municipal Llao Llao. Another option is to extend it to match the boundaries and look for an articulated management.

\section{References}

Bustillo E (1999) El despertar de Barilche [The Awakening of Bariloche]. Buenos Aires: Sudamericana.

Dudley N (2008) Directrices para la aplicación de las categorías de gestión de áreas protegidas [Guidelines for the application of the management categories of protected areas]. Gland, Suiza, UICN.

Guevara T (2015) La ciudad para quién? Transformaciones territoriales, políticas urbanas y procesos de producción del hábitata en la ciudad de Buenos Aires (1996-2011) [The city for whom? Territorial transformations, urban policies and production processes hábitata in the city of Buenos Aires. 1996-2011]. México DF: Universidad Nacional Autónoma de México/Programa Universitario de Estudios sobre la Ciudad/Instituto Fondo Nacional Vivienda para los Trabajadores.

Hiernaux D (2006) Geografía del turismo [Geography of Tourism] en Lindón and Hiernaux (Eds.) Tratado de geografía humana [Human Geography Treatise]. Barcelona: Anthropos \& Universidad Autónoma Metropolitana, pp. 401-432.

Lolich L (2010) Patagonia. Patrimonio arquitectónico [Patagonia. Architectural Heritage]. Neuquén: Educo Univ. Nac del Comahue. 
Matossian B (2013) Chilenos en San Carlos de Bariloche; barrios populares, imaginarios y tensiones en una ciudad de frontera [Chileans in San Carlos de Bariloche; popular, imaginary and tensions in a city neighborhoods border]. In A Núñez et al. (Eds.) Fronteras en movimiento e imaginarios geo-gráficos. La cordillera de Los Andes como espacialidad sociocultural [Moving borders and imaginary geo-graphics. The Los Andes Mountains as a sociocultural spaciality]. Santiago, Chile: RIL, pp. 137-162.

Municipality of San Carlos de Bariloche (2010). Plan de Ordenamiento Territorial [Territorial Organization Plan].

Navarro Floria P (1999) Historia de la Patagonia [History of Patagonia]. Buenos Aires: Ciudad Argentina.

Núñez P (2011) Distancias entre la ecología y la praxis ambiental: una lectura crítica desde el ecofeminismo [Distances between ecology and environmental practice: a critical reading from ecofeminism]. La Plata: Universidad Nacional de La Plata.

Oglietti G, et al. (2014) Relevamiento socioeconómico. Reserva Natural Urbana Lago Morenito y Laguna Ezquerra [Socioeconomic Survey. Morenito Lake and Ezquerra Lagoon Natural Urban Reserve]. Universidad Nacional de Río Negro/Municipalidad de San Carlos de Bariloche.

Otero A, González R (2012) La sombra del turismo. Movilidades y desafíos de los destinos turísticos con migración de amenidad [The Shadow of Tourism. Mobilities and Challenges of Tourist Destinations with Amenity Migration]. Neuquén, Argentina: Educo.

Stefanick L, González R (2012) En busca del paraíso. Migración por amenidad y la crisis de crecimiento de los pueblos de montaña del oeste canadiense [In search of paradise. Amenity migration and growth crisis of mountain villages of Western Canada]. In Estudios y Perspectivas en Turismo [Studies and Perpsectives in Tourism] No.: 21. Buenos Aires: Centro de Investigaciones y Estudios Turísticos (CIET), pp. 1114-1141.

Vallmitjana R (1989) Bariloche, mi pueblo [Bariloche, my Town]. Buenos Aires: Fundación Antorchas.

Vallmitjana R (1993) 90 años de Turismo en Bariloche [Ninety years of Tourism in Bariloche]. Bariloche: Asociación Hotelera Gastronómica.

Vejsbjerg L, Núñez P, Matossian B (2014) Transformation of Frontier National Parks into Tourism Sites. The North Andean Patagonia Experience (1934-1955). AlmaTourism p. 10. 